\title{
Carbon and Nitrogen Stocks and Burial Rates in Intertidal Vegetated Habitats of a Mesotidal Coastal Lagoon
}

\author{
Márcio Martins, ${ }^{1}$ Carmen B. de los Santos, ${ }^{1}$ Pere Masqué,,${ }^{2,3,4,5}$ \\ A. Rita Carrasco, ${ }^{6}$ Cristina Veiga-Pires,${ }^{6}$ and Rui Santos ${ }^{1 *}$
}

\begin{abstract}
${ }^{1}$ CCMAR - Centre of Marine Sciences, University of Algarve, Faro, Portugal; ${ }^{2}$ International Atomic Energy, 4a Quai Antoine 1er, 98000 Principality of Monaco, Monaco; ${ }^{3}$ School of Science and Centre for Marine Ecosystems Research, Edith Cowan University, Joondalup, WA 6027, Australia; ${ }^{4}$ Institut de Ciència I Tecnologia Ambientals, Universitat Autònoma de Barcelona, 08193 Bellaterra, Barcelona, Spain; ${ }^{5}$ Departament de Física, Universitat Autònoma de Barcelona, 08193 Bellaterra, Barcelona, Spain; ${ }^{6}$ CIMA - Centre for Marine and Environmental Research, FCT, Universidade Do Algarve, Campus de Gambelas, 8005-139 Faro, Portugal
\end{abstract}

\begin{abstract}
Coastal vegetated ecosystems such as saltmarshes and seagrasses are important sinks of organic carbon (OC) and total nitrogen (TN), with large global and local variability, driven by the confluence of many physical and ecological factors. Here we show that sedimentary OC and TN stocks of intertidal saltmarsh (Sporobolus maritimus) and seagrass (Zostera noltei) habitats increased between two- and fourfold along a decreasing flow velocity gradient in Ria Formosa lagoon (south Portugal). A similar twofold increase was also observed for OC and TN burial rates of $S$. maritimus and of almost one order of magnitude for $Z$. noltei. Stable isotope mixing
\end{abstract}

Received 14 October 2020; accepted 20 May 2021

Supplementary Information: The online version contains supplementary material available at https://doi.org/10.1007/s10021-021-0066 0-6.

Author contributions: MM: Methodology, Formal analysis, Investigation, Data curation, Visualization, Writing - original draft. CBdls: Methodology, Supervision, Investigation, Writing-review and editing. RS: Conceptualization, Supervision, Methodology, Funding acquisition, Resources, Writing-review and editing. CV-P: Conceptualization, Supervision, Methodology, Resources, Writing-review and editing. PM: Methodology, Formal analysis, Resources, Writing-review and editing. ARC: Methodology, Funding acquisition, Resources, Writing-review and editing.

*Corresponding author; e-mail: rosantos@ualg.pt models identify allochthonous particulate organic matter as the main source to the sedimentary pools in both habitats (39-68\%). This is the second estimate of OC stocks and the first of OC burial rates in $Z$. noltei, a small, fast-growing species that is widely distributed in Europe $(41,000$ ha) and which area is presently expanding (8600 ha in 2000s). Its wide range of OC stocks $\left(29-99 \mathrm{Mg} \mathrm{ha}^{-1}\right)$ and burial rates $\left(15-122 \mathrm{~g} \mathrm{~m}^{2} \mathrm{y}^{-1}\right)$ observed in Ria Formosa highlight the importance of investigating the drivers of such variability to develop global blue carbon models. The TN stocks (7-11 $\left.\mathrm{Mg} \mathrm{ha}^{-1}\right)$ and burial rates $\left(2-4 \mathrm{~g} \mathrm{~m}^{-2} \mathrm{y}^{-1}\right)$ of $Z$. noltei were generally higher than seagrasses elsewhere. The OC and TN stocks (29-101 and 3-11 Mg ha ${ }^{-1}$, respectively) and burial rates (19-39 and 3-5 $\mathrm{g} \mathrm{m}^{-2} \mathrm{y}^{-1}$ ) in $S$. maritimus saltmarshes are generally lower than those located in estuaries subjected to larger accumulation of terrestrial organic matter.

Key words: Blue carbon; Nitrogen; Seagrass; Saltmarsh; Sediment stocks; Burial rates; Flow current velocity. 


\section{HighLights}

- First assessment of OC and TN burial rates and TN stocks of the seagrass $Z$. noltei.

- High variability of OC and TN stocks and burial rates of saltmarsh and seagrasses.

- Carbon/nitrogen storage and sequestration decrease with flow current velocity.

\section{INTRODUCTION}

Coastal blue carbon sequestration, that is, the organic carbon accumulated and stored in coastal vegetated ecosystems such as saltmarshes, mangroves and seagrasses, is a significant process at a global scale (Nellemann and others 2009). These ecosystems are receiving increasing attention for their disproportional ability to remove atmospheric $\mathrm{CO}_{2}$ and store it as organic carbon in their sediments on a long-term basis (hundred to million years). This carbon represents $50 \%$ of the total carbon of marine sediments, while occupying only about $2 \%$ of the ocean surface (Duarte and others 2005). Still, their contribution to the global carbon budget remains largely overlooked (Duarte 2017; Macreadie and others 2019). Indeed, the recent IPCC report (IPCC 2019) referred to these ecosystems for the first time, highlighting the need to improve the quantification of their carbon storage to reduce current uncertainties around measurement, reporting and verification. Equally important, blue carbon ecosystems are relevant in other major global biogeochemical cycles, for example, the nitrogen cycle (Jordan and others 2011; Erisman and others 2013).

Most of the organic carbon (OC) and total nitrogen (TN) stocks in coastal vegetated habitats are in the sediment, with a smaller fraction being held in standing biomass (Duarte and others 2013; Bulmer and others 2016; Serrano and others 2019). These sedimentary stocks originate from the burial of both autochthonous and allochthonous organic matter (Hendriks and others 2008; Kennedy and others 2010). The size of OC and TN stocks is driven by a balance between the rate at which these elements are buried and the rate at which they are remineralized, which is controlled by a wide range of biotic and abiotic parameters (Mateo and others 1997; Burdige 2007; Koho and others 2013; Macreadie and others 2014). Hydrodynamic energy, for example, is negatively related to grain size, with fine sediments being associated with low hydrodynamics and thus low-energy sediment deposi- tional areas (Christiansen and others 2000; Mazarrasa and others 2017; Santos and others 2019). In turn, mud content is highly predictive of organic carbon content in sediments as smaller size particles are associated with higher OC contents (Bergamaschi and others 1997; Dahl and others 2016; Röhr and others 2016; Mazarrasa and others 2017) and lower remineralization rates (Burdige 2007; Kennedy and others 2010; Schmidt and others 2011; Koho and others 2013). The hydrodynamic regime (for example, hydroperiod and current velocities) acting on seagrasses and saltmarshes can also affect the ratio of allochthonous vs. autochthonous organic matter contribution in the sediment, by altering the organic matter import and export rates to the habitat (Hyndes and others 2014).

Information on carbon stocks and burial rates in coastal vegetated ecosystems has grown rapidly over the past few years (Duarte 2017; Macreadie and others 2017; Serrano and others 2018), but global estimates still suffer from bias towards certain species and locations. Organic carbon stocks in seagrass meadows can vary up to 18 -fold among species (Lavery and others 2013). In saltmarshes, large variations in OC stocks occur also among species and among hydrodynamic regimes (Ouyang and Lee 2014). Despite the increasing number of studies on blue carbon stocks, the contribution of some seagrass species, in particular small fast-growing species, is still underrepresented (Mazarrasa and others 2018). For example, there is only one estimate of the blue carbon stocks for the species addressed here, Zostera noltei, which covers a wide, expanding area in Europe $(41,072$ ha with a net gain of 8589 ha during the 2000s; de los Santos and others 2019). In addition, there has been more focus on the blue carbon stocks of seagrass meadows than of saltmarshes, which are commonly cooccurring habitats (Ouyang and Lee 2014).

Mesotidal coastal lagoons, where seagrass meadows and saltmarshes commonly co-exist, are some of the most vulnerable ecosystems on Earth as they are exposed to many human impacts derived from resource exploitation, coastal works and global changes such as sea level rise (Murray and others 2019; Deegan and others 2012). The Ria Formosa lagoon, in South Portugal, is an example of such ecosystems. It was declared a Natural Park in 1987 to secure its ecological values, but it is still under the effects of a high human pressure. This has resulted in the decline of seagrass coverage due to the establishment of clam farms, clam digging, propeller scarring and anchoring (Cunha and others 2013). 
The present work aims to quantify the sedimentary organic carbon (OC) and total nitrogen (TN) stocks, burial rates and the source of such stocks in intertidal coastal vegetated habitats of the Ria Formosa lagoon. The study was conducted along a flow velocity gradient as established in Santos and others (2019) in the vegetated low intertidal, where the saltmarsh species Sporobolus maritimus (Curtis) P.M. Peterson \& Saarela (formerly Spartina maritima (M. A. Curtis) Fern.) and the seagrass Zostera noltei Hornemann co-occur. The $\mathrm{OC}$ and TN stocks and burial rates in Ria Formosa lagoon were compared to values reported elsewhere to evaluate their relative importance and how underrepresented species such as $Z$. noltei may influence global estimates of carbon sequestration.

\section{Materials and Methods}

\section{Study Area and Sampling}

Ria Formosa is a coastal lagoon system located along the southern Portuguese coast, extending across $56 \mathrm{~km}$ (Figure 1). It is separated from the ocean by two peninsulas and five barrier islands and connected to it through six inlets. The lagoon is subjected to a mesotidal semi-diurnal regime, with amplitudes ranging from 1.3 to $3.5 \mathrm{~m}$ on neap and spring tides, respectively, with the intertidal area largely colonized by the seagrass $Z$. noltei and the saltmarsh $S$. maritimus. The system receives little freshwater inputs from rivers (Malta and others 2017), and water circulation is mostly driven by tides (Jacob and others 2013). The sediment varies from coarse sand along the channels near the inlets to muddy sand and mud towards to the hinterland areas. Ria Formosa is subject to both natural sedimentary processes and anthropogenic modifications, including high nitrogen loads from wastewater treatment plants and groundwater inputs (Malta and others 2017), dredging of the navigation channels (Ferreira and others 2016) and physical impacts related to clam digging (Cabaço and others 2005). The artificial opening in 1929 and later stabilization of the main inlet (Faro-Olhão, Figure 1) had a particular impact in the morphology and tide circulation in the system.

Four intertidal sampling stations were selected along a flow velocity gradient (Figure 1), from stations S1 to S4 (Santos and others 2019). The median flow velocity at each station was $0.34,0.33$, 0.24 and $0.21 \mathrm{~m} \mathrm{~s}^{-1}$, from stations S1 to S4 (as modelled by Carrasco and others 2018). Station S1 was located at the main navigation channel near the main inlet, whereas stations S2-S4 were lo- cated along a tributary channel, in sheltered locations (Figure 1).

Sediment cores were collected in January and February 2017 in each station, within the lower intertidal seagrass Z. noltei (ZN) and above it, within the contiguous saltmarsh $S$. maritimus (SM). Cores are named hereafter as the habitat (ZN or SM) and the station number (for example, ZNl, for Z. noltei in station S1). Sediment cores were extracted by manually hammering PVC pipes $(160 \mathrm{~cm}$ length, $4.8 \mathrm{~cm}$ internal diameter) into the sediment, with a penetration depth ranging from 120 to $160 \mathrm{~cm}$. Sediment compaction during coring was measured as the difference in surface sediment elevation inside and outside the core (Glew and others 2001) and ranged from 15 to $44 \%$. All results presented hereafter refer to equivalent decompressed depths. The cores were sealed at both ends, transported to the laboratory in vertical position, and immediately halved longitudinally and sliced every $2 \mathrm{~cm}$. Slices were subdivided for various analytical procedures and frozen at $-20{ }^{\circ} \mathrm{C}$ until processing.

\section{Geochemical Analyses}

Geochemical analyses were conducted every other $2 \mathrm{~cm}$ along the upper $50 \mathrm{~cm}$. Below $50 \mathrm{~cm}$, samples were collected when changes in sediment texture and colours were observed, at the start and at the end of each layer. An additional slice was collected in the middle of layers that were thicker than $30 \mathrm{~cm}$. Sediment samples were extracted from each slice with volumetric tubes (ranging from 1 to 7.5 $\left.\mathrm{cm}^{3}\right)$, lyophilized $(24 \mathrm{~h})$, weighted (dry weight, $\mathrm{dw}, \pm 0.0001 \mathrm{~g})$ to determine dry bulk density (DBD, $\mathrm{g} \mathrm{dw}^{-3}$ ) and ground to fine powder (Fritsh planetary ball mill, using agate material). A subsample of ca. $0.5 \mathrm{~g} \mathrm{dw}$ was used for elemental and isotopic determination at UH Hilo Analytical Laboratory (Hawaii, USA). Organic carbon content $(\mathrm{OC}, \% \mathrm{dw})$ and $\delta^{13} \mathrm{C}(\%$ relative to Vienna Pee Dee Belemnite; $\pm 0.2 \%$ ) were determined after removal of inorganic carbon by direct addition of $1 \mathrm{M} \mathrm{HCl}$. The OC content of sediment was referred to the initial mass before acidification. Total nitrogen content $(\mathrm{TN}, \% \mathrm{dw})$ and $\delta^{15} \mathrm{~N}(\%$ relative to Air; $\pm 0.2 \%$ ) were determined on non-acidified samples. A second subsample was subjected to loss on ignition analysis $\left(450^{\circ} \mathrm{C}, 4 \mathrm{~h}\right)$ to determine organic matter content (OM, \% dw). A third subsample was used to determine mud sediment content $(<63 \mu \mathrm{m}, \% \mathrm{dw})$ by wet sieving after removal of dissolved salts with distilled water $(24 \mathrm{~h})$ and organic matter digestion with hydrogen peroxide in increasing concentrations, up to $30 \%$. The sedi- 


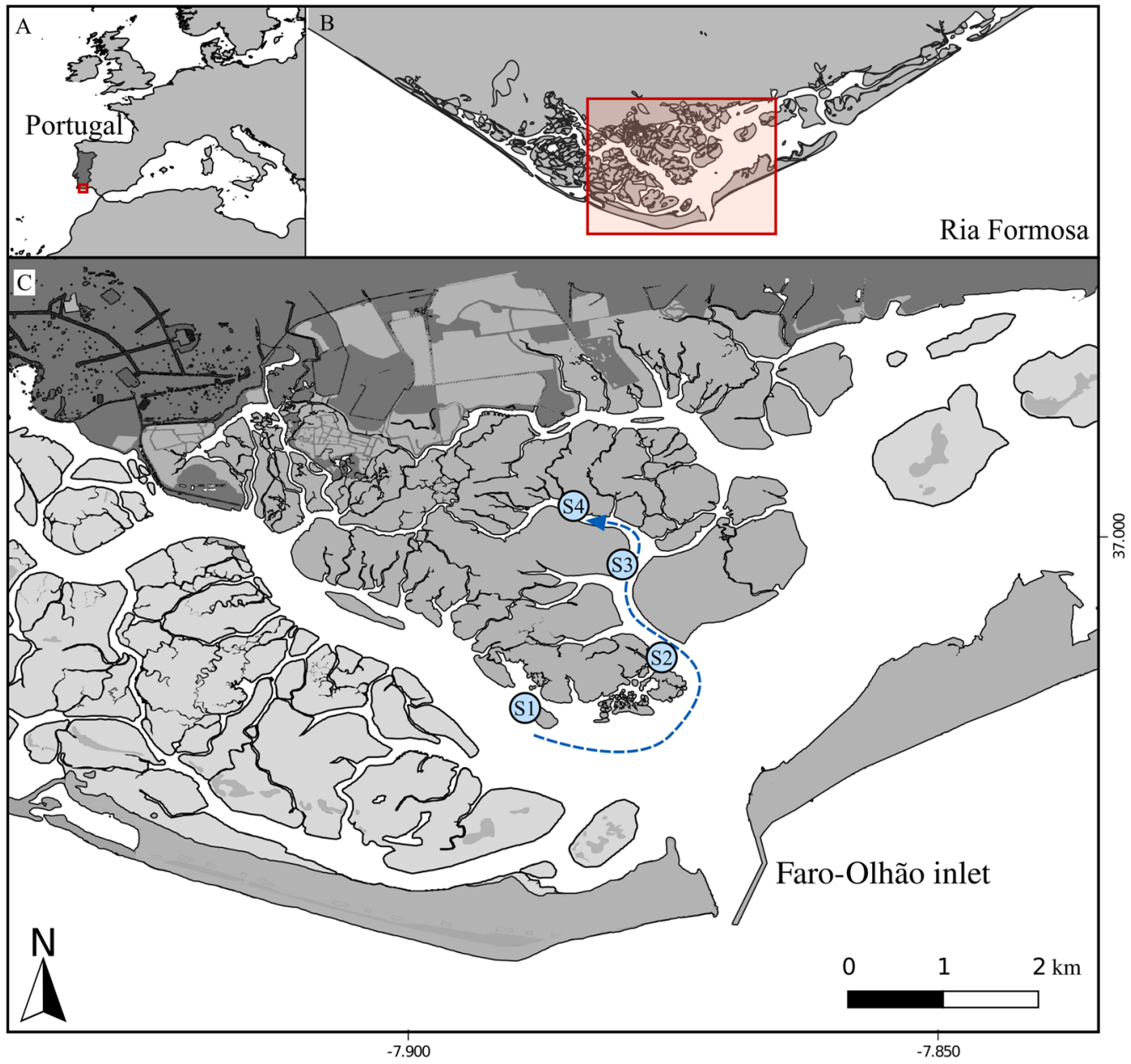

Figure 1. Location of the sampling stations (from the most exposed station, S1, to most sheltered one, S4) in Ria Formosa lagoon (South Portugal). Current flow velocities decrease along the dashed arrow.

ment stocks of OC and TN $\left(\mathrm{Mg} \mathrm{ha}^{-1}\right)$ were estimated to a standardized depth of $1 \mathrm{~m}$ by multiplying OC or TN contents (\% dw) by DBD $\left(\mathrm{g} \mathrm{cm}^{-3}\right)$, and depth integrating the $\mathrm{OC}$ and $\mathrm{TN}$ contents using the trapezoidal rule (https://www.intmath.c om/integration/5-trapezoidal-rule.php), that is, summing the areas of all trapezes of the graphs of OC or TN values along sediment depth.

\section{Sediment Accumulation and Burial Rates}

The sediment cores were analysed for $210 \mathrm{~Pb}$ at Edith Cowan University to estimate the sedimentation rates during the last decades/century following Sánchez-Cabeza and others (1998). Aliquots of each sample along the upper layers of the sediment cores were acid-digested after addition of 209Po as an internal tracer, and the concentrations of $210 \mathrm{~Pb}$ were determined by alpha spectrometry through the measurement of $210 \mathrm{Po}$, assuming secular equilibrium between $210 \mathrm{~Pb}$ and
210Po. Supported ${ }^{210} \mathrm{~Pb}$ was calculated from its constant concentrations at depth and ${ }^{226} \mathrm{Ra}$ (determined by gamma spectrometry) in selected samples along each core. The concentrations of excess ${ }^{210} \mathrm{~Pb}$, used for the age models, were estimated as the difference between total ${ }^{210} \mathrm{~Pb}$ and supported ${ }^{210} \mathrm{~Pb}$. Both the Constant Rate of Supply (CRS, Appleby and Oldfield 1978) and the Constant Flux: Constant Sedimentation (CF:CS; Krishnaswamy and others 1971) models were applied when possible, following the recommendations detailed in Arias-Ortiz and others (2018). When both models could be applied, the mass and sediment accumulation rates (MAR, $\mathrm{g} \mathrm{cm}^{-2} \mathrm{y}^{-1}$ and SAR, $\mathrm{cm} \mathrm{y}^{-1}$ ) were estimated as the average of both models (Supplementary material, Table S1).

Although the ${ }^{210} \mathrm{~Pb}$ dating technique allowed us to determine the OC and TN accumulation rates in five cores (SM3, SM4, ZN1, ZN3, and ZN4; Supplementary material, Figure $\mathrm{S} 1$ ), the concentration 
profiles of excess ${ }^{210} \mathrm{~Pb}$ in cores SM1, SM2 and ZN2 could not be used to obtain an age model due to mixing of sediments along them. This is common in coastal vegetated ecosystems of heterogeneous sediments with varying inputs of organic material, which are disturbed by natural and anthropogenic processes resulting in sediment mixing and changes in sedimentation or erosion rates (Arias-Ortiz and others 2018). As an alternative for these cores (SM1, SM2 and ZN2), an historical reconstruction was performed based on a common sudden change from superficial horizons characterized by thinner sediment and darker colour to deeper horizons with coarser sediment and light colour. The intrusions of coarser sediments in those stations were assumed to have occurred during the period from 1929 to 1955 relative to the artificial opening and subsequent stabilization of the Faro-Olhão inlet (Pacheco and others 2011). Sediment accumulation rates for these were estimated dividing the depth of the superficial horizon by 62 years, the time interval since the works of the inlet opening ended and the sediment sampling. The OC and TN burial rates $\left(\mathrm{g} \mathrm{m}^{-2} \mathrm{y}^{-1}\right)$ were calculated as the product of the average sediment accumulation rates $\left(\mathrm{SAR}, \mathrm{m} \mathrm{y}^{-1}\right.$ ) and the average $\mathrm{OC}$ or $\mathrm{TN}$ densities $\left(\mathrm{g} \mathrm{m}^{-3}\right)$ along the core.

We used the sand intrusion event observed in $\mathrm{ZNl}$ at $31 \mathrm{~cm}$ depth to validate the $210 \mathrm{~Pb}$ chronology. This sandy layer was assumed to originate from the artificial opening, which occurred from 1929 and 1955. The age of this layer estimated by $210 \mathrm{~Pb}$ chronology lies between 1929 and 1942, which corresponds to the period of the artificial inlet opening.

\section{Organic Matter Sources}

The contributions of the main source of organic matter $(\mathrm{OM})$ to the sedimentary organic matter pool were determined using Stable Isotope Mixing Models (SIMMR version 0.3, Parnell 2019). Models were ran with 2 tracers, $\delta^{13} \mathrm{C}$ (\%o vs VPDB) and $\delta^{15} \mathrm{~N}$ (\% vs Air) of the sediment samples and of the potential OM sources. All sediment layers were included in the analysis, except those with very low mud and OM contents due to exogeneous sand intrusions because they do not represent the natural vegetated habitat. Changes of isotopic values along sediment depth were minor.

Markov Chain Monte Carlo simulations (chain length of 100,000, burn-in size of 50,000, thinning amount of 50 and 3 chains) were carried out to reveal the significant contributors. The potential OM sources in the area were considered to be Sporobolus maritimus (SMt), Zostera noltei (ZNt), microphytobenthos (Mic), macroalgae (Mac) and particulate organic matter in the water column (POM). The autochthonous contributions were those derived from within the meadow (the dominant macrophyte and microphytobenthos), whereas the allochthonous contributions were POM, macroalgae and the other macrophytes (SMt in $\mathrm{ZN}$ sediments, ZNt in SM sediments). We are aware that increasing the number of sources beyond $n+1$, where $n$ is the number of tracers, increases the uncertainty of results (Parnell and others 2010). However, the model was run with various number of sources and the main results were not affected. Samples of potential sources were collected in situ and pooled with previously recorded data (Machás and others 2003; Santos, R. unpublished data). The $\delta^{13} \mathrm{C}$ (mean $\pm \mathrm{SD}$ ) for the potential sources was: $-15.3 \pm 1.3 \%$ for Mac $(n=12) ;-14.3$ for Mic $(n=1) ;-20.8 \pm 0.9 \%$ for POM $\quad(n=21) ;-13.2 \pm 0.6 \%$ for SMt $(n=18)$; and $-10.3 \pm 0.8 \%$ for $\mathrm{ZNt}(n=48)$. $\delta^{15} \mathrm{~N}$ signatures were (same sample size) $8.8 \pm 1.1$ $\%$ for Mac; 5.4 for Mic; $3.9 \pm 2.2 \%$ for POM; $6.8 \pm 1.7 \%$ for SMt; and $6.1 \pm 1.9 \%$ for ZNt.

\section{Statistical Analyses}

Data are shown as mean \pm SD unless otherwise stated. Assumptions of normality and homoscedasticity were checked by inspection of residual plots. The relationships between $\mathrm{OM}$ and mud contents and OC or TN contents were obtained by OLS regression after testing the significance of habitat in those relationships using a 2way ANCOVA, with OM (continuous) and habitat (2 levels: ZN and SM), and their interaction as fixed factors. Differences between sediment properties (OM and mud contents) among sampling stations and between habitats were tested using weighted type III two-way ANOVA, using habitat (2 levels: ZN and SM) and station (4 levels: S1 to S4) and their interaction as fixed factors. The weight of each sample corresponded to the layers along the core. Tukey pairwise comparisons were used to test for differences in mean $\mathrm{OM}$ and mud contents among the factor levels. A critical $\alpha$ level of significance of 0.05 was used. Data and statistical analyses were performed in R programming language, version 3.5.1 (R Core Team 2018). 


\section{Results}

\section{Sediment Profiles and Stocks}

The OC, TN and mud contents of profiles in each site were similar within each vegetated habitat of Ria Formosa lagoon (Figure 2). The OC content of sediment profiles was one order of magnitude higher than TN, ranging between 0.05 and $4.25 \%$, whereas $\mathrm{TN}$ ranged from 0 to $0.44 \%$ (Figure 2). In general, OC, TN and mud contents at $S$. maritimus and Z. noltei habitats were higher in the sediment surface and declined with depth, although no particular trends could be observed. For cores SMI and SM2, OC, TN and mud contents showed sharp decreases from the surface to $c a .20 \mathrm{~cm}$ depth (Figure 2), where sandy layers with low OC and TN contents were present down to $85 \mathrm{~cm}$ in SMl and to $62 \mathrm{~cm}$ in SM2. Below these sandy layers, OC, TN and mud contents pronouncedly increased in SM2, and to a lesser extent in SMl. This suggests that an event of accumulation of sandy sediments occurred in the main navigation channel, probably related to

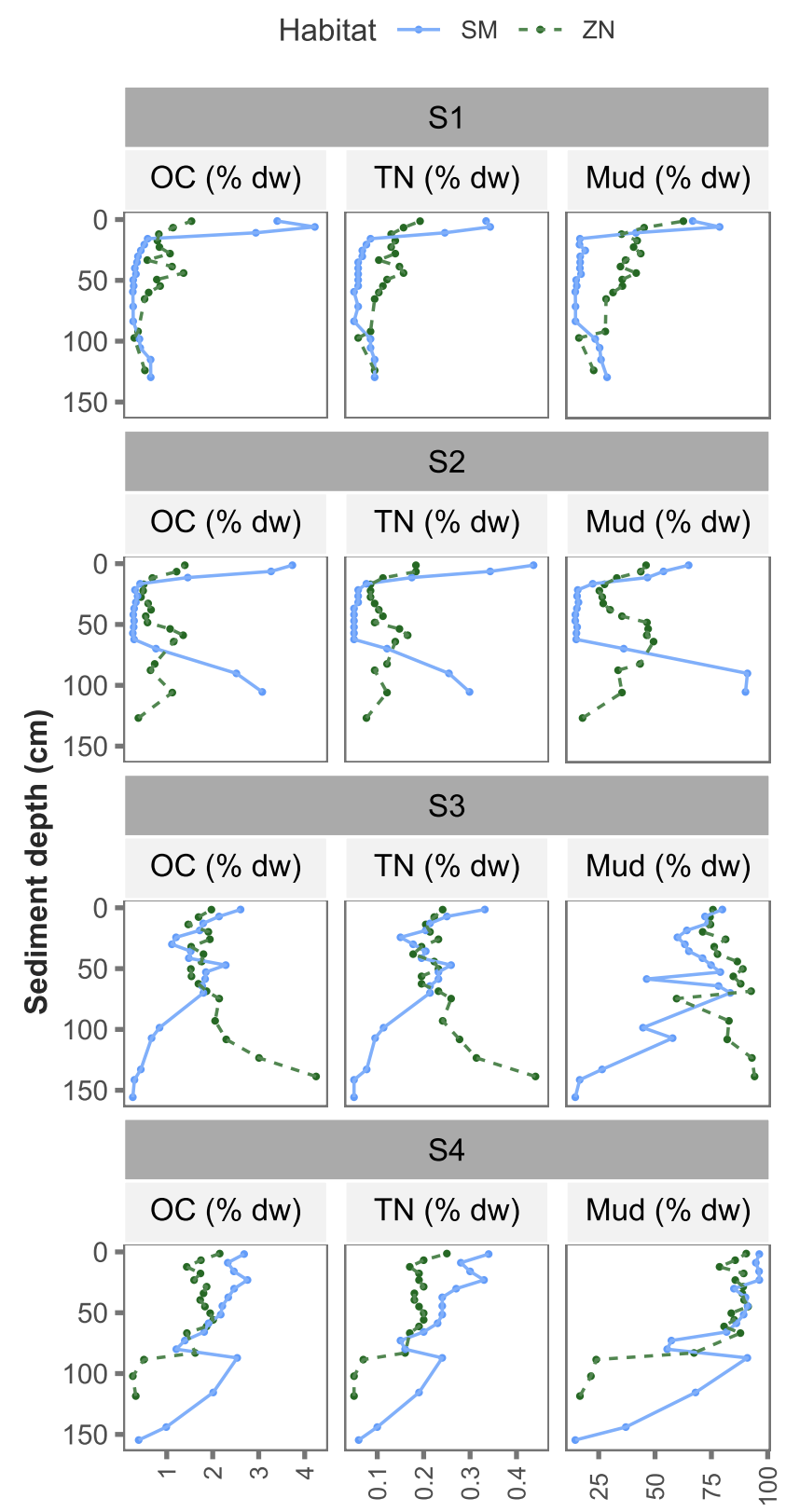

Figure 2. Sediment depth profiles of organic carbon (OC, \% dw), mud (\% dw) and total nitrogen (TN, \% dw) contents in saltmarsh Sporobolus maritimus (blue, continuous line) and seagrass Zostera noltei (green, dashed line) habitats along the current flow gradient, from sampling stations S1 to S4. 
the artificial opening of the Faro-Olhão inlet in 1929, which had a smaller impact in SM2, that lies in the entrance of a secondary channel. $\mathrm{ZNl}$ and ZN2 sites show the same trend, albeit less pronounced (Figure 2). OC, TN and mud contents of cores SM3 and SM4 generally decreased with sediment depth, whereas in ZN3 and ZN4 values remained constant down to $c a 60 \mathrm{~cm}$ depth, after which OC and TN decreased in ZN4 and increased in $\mathrm{ZN} 3$, reaching a maximum of $4.25 \%$ OC and $0.44 \% \mathrm{TN}$ at $139 \mathrm{~cm}$.

The linear relationships of OM content with both OC and TN were similar between habitats (Supplementary material, Table S2). Across habitats and stations, OM content was highly and positively related to OC and TN (Supplementary material, Figure S2). Sedimentary OM and mud contents increased significantly along the flow velocity gradient from stations S1 to $\mathrm{S} 4 \quad\left(\mathrm{~F}_{(3,128)}=9.6\right.$, $p<0.001$, Figure $3 \mathrm{~A}$, and $\left.\mathrm{F}_{(3,}, 128\right)=25.2$, $p<0.001$, Figure 3B, respectively), but did not differ between habitats $\left(\mathrm{F}_{(1,128)}=0.1, p>0.05\right.$ and $\mathrm{F}_{(1,128)}=1.587, p>0.05$, respectively). OC stocks in the upper meter in S. maritimus varied threefold, ranging from $29 \mathrm{Mg} \mathrm{OC} \mathrm{ha}{ }^{-1}$ in Sl to $101 \mathrm{Mg} \mathrm{OC} \mathrm{ha}^{-1}$ in S4 (Figure 3C). In Z. noltei, OC stocks varied by a factor of 2 , increasing from $47 \mathrm{Mg} \mathrm{OC} \mathrm{ha}{ }^{-1}$ in Sl to $99 \mathrm{Mg}$ OC ha-1 in S4 (Figure 3C). The same trend was observed in $\mathrm{TN}$ stocks, which ranged from minima of $3 \mathrm{Mg} \mathrm{TN} \mathrm{ha}{ }^{-1}$ and $7 \mathrm{Mg} \mathrm{TN} \mathrm{ha}^{-1}$ in S1, for S. maritimus and Z. noltei, respectively, to maxima of around $11 \mathrm{Mg} \mathrm{TN} \mathrm{ha}^{-1}$ in S3 for S. maritimus and in S4 for Z. noltei (Figure 3D).

\section{Sediment Accumulation and OC and TN Burial Rates}

The pattern of variation in SAR at S. maritimus and $Z$. noltei habitats along the flow current gradient is not as clear as OC and TN stocks (Table 1). SAR at the saltmarsh was about twofold higher at $\mathrm{S} 3$ and S4 (3.08 and $\left.3.62 \mathrm{~mm} \mathrm{y}^{-1}\right)$ than at S1 and S2 (1.51 and $1.59 \mathrm{~mm} \mathrm{y}^{-1}$; Table 1), whereas for Z. noltei, SAR was more variable among stations, ranging
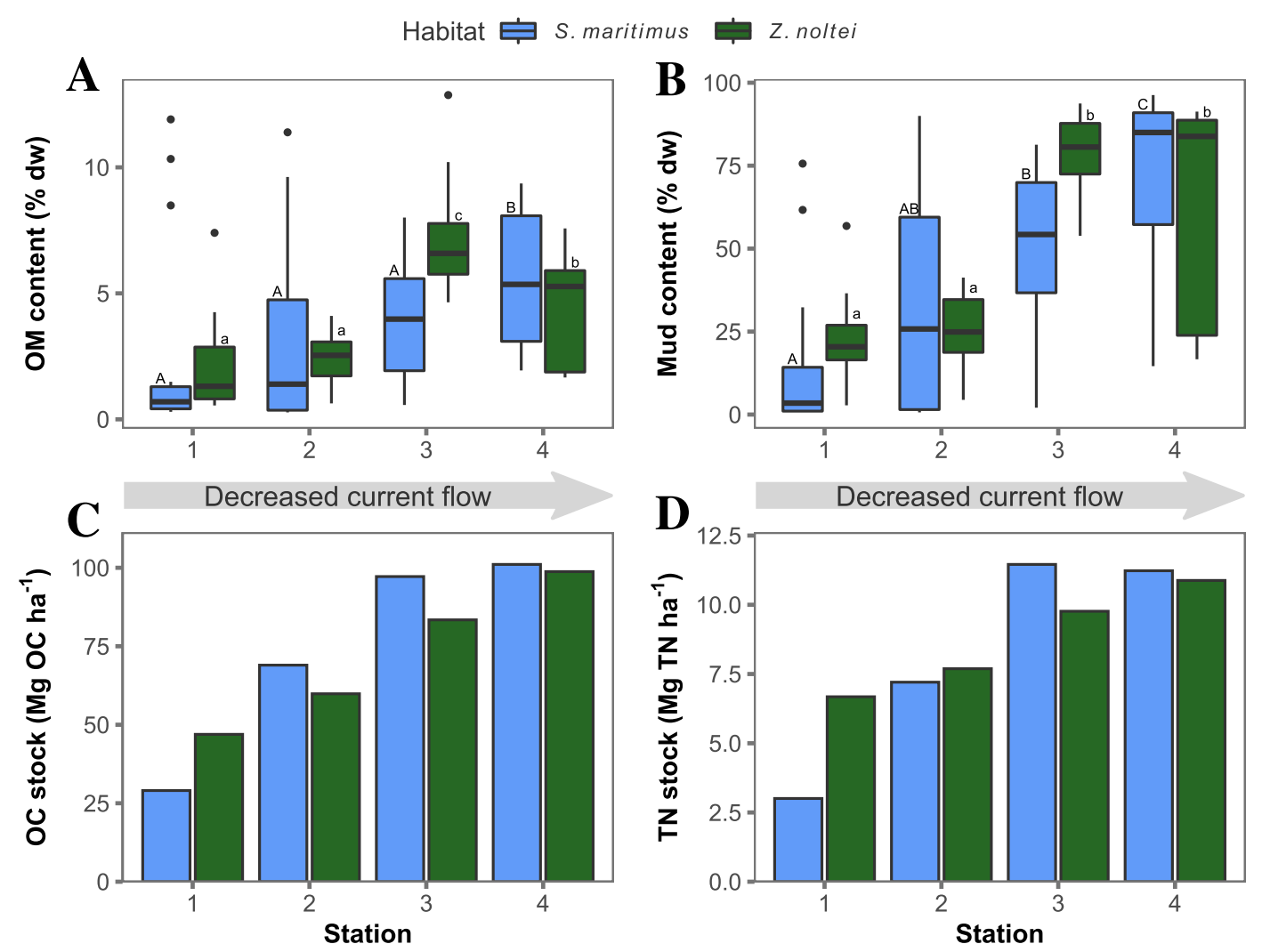

Figure 3. Variation in (A) organic matter (OM) content (\% dw), (B) mud content (\% dw), (C) organic carbon (OC) stock $\left(\mathrm{Mg} \mathrm{ha}^{-1}\right)$ and $(\mathrm{D})$ total nitrogen (TN) stock $\left(\mathrm{Mg} \mathrm{ha}^{-1}\right)$, in the sediment of Sporobolus maritimus and Zostera noltei along the current flow gradient, from sampling stations S1 to S4. The thick centre line represents the median, hinges indicate the 25 th and 75th quantiles, whiskers indicate the 5th and 95th quantiles, and outliers are plotted as dots. Letters over the boxplots indicate statistical differences among stations (two-way ANOVA, Tukey pairwise comparisons, $p<0.05$ ) for $Z$. noltei (lower case) and S. maritimus (upper case). 
Table 1. Sediment Accumulation Rates (SAR), Organic Carbon (OC) and Total Nitrogen (TN) Burial Rates Estimated for the Past 50 Years in Saltmarsh Sporobolus maritimus (SM) and Seagrass Zostera noltei (ZN) Sediment Cores at Four Stations Located Along a Flow Velocity Gradient (From Most Exposed Station S1 to Most Sheltered Station S4) in the Ria Formosa Lagoon

\begin{tabular}{lllll}
\hline Core & SAR $\left(\mathrm{mm} \mathrm{y}^{-1}\right)$ & OC burial rate $\left(\mathrm{g} \mathrm{m}^{-2} \mathrm{y}^{-1}\right)$ & TN burial rate $\left(\mathrm{g} \mathrm{m}^{-2} \mathrm{y}^{-1}\right)$ & SAR estimation method \\
\hline SM1 & 1.51 & 24.02 & 2.07 & Historical reconstruction \\
SM2 & 1.59 & 19.35 & 2.14 & Historical reconstruction \\
SM3 & $3.62 \pm 0.21$ & $39.36 \pm 2.29$ & $4.64 \pm 0.27$ & $210 \mathrm{~Pb}$ \\
SM4 & $3.08 \pm 0.27$ & $33.95 \pm 2.96$ & $4.21 \pm 0.37$ & $210 \mathrm{~Pb}$ \\
ZN1 & $3.69 \pm 0.26$ & $23.06 \pm 1.65$ & $3.16 \pm 0.22$ & $210 \mathrm{~Pb}$ \\
ZN2 & 1.64 & 15.20 & 2.02 & Historical reconstruction \\
ZN3 & $15.76 \pm 0.75$ & $121.97 \pm 5.82$ & $14.42 \pm 0.69$ & $210 \mathrm{~Pb}$ \\
ZN4 & $4.35 \pm 0.45$ & $39.25 \pm 4.14$ & $4.49 \pm 0.47$ & $210 \mathrm{~Pb}$
\end{tabular}

The age dating method used to estimate the SAR is also presented. Values represent mean $\pm S D$ for estimations from models CRS and CF:CS.

from 1.64 at $\mathrm{ZN} 2$ to $15.76 \mathrm{~mm}^{-1}$ at sheltered station ZN3 (Table 1). Estimated OC and TN burial rates ranged from 19.35 to $39.36 \mathrm{~g} \mathrm{~m}^{-2} \mathrm{y}^{-1}$ and 2.07 to $4.64 \mathrm{~g} \mathrm{~m}^{-2} \mathrm{y}^{-1}$, respectively, for $S$. maritimus and from 15.20 to $121.97 \mathrm{~g} \mathrm{~m}^{-2} \mathrm{y}^{-1}$ and 2.02 to $14.42 \mathrm{~g} \mathrm{~m}^{-2} \mathrm{y}^{-1}$, respectively, for $Z$. noltei (Table 1).

\section{Sources of organic matter}

The ranges of variability of $\delta^{13} \mathrm{C}$ and $\delta^{15} \mathrm{~N}$ of the sediment samples were similar for $S$. maritimus and Z. noltei and fell within the polygon delimited by the isotopic signatures of the potential OM sources (Figure 4). The mixing model results indicated that water column, allochthonous POM, was the main source of sedimentary OM in all stations and both habitats, contributing on average between 39 and $68 \%$ to the OM sedimentary pool (Figure 5). The autochthonous contributions to sedimentary OM are quite similar between the saltmarsh and the seagrass habitats, varying from 28 to $36 \%$ and from 19 to $40 \%$, respectively (Figure 5).

\section{Discussion}

\section{OC and TN Stocks and Burial Rates}

Our results show that OC and TN sediment stocks of the upper meter of vegetated intertidal habitats of Ria Formosa, the seagrass $Z$. noltei and the saltmarsh $S$. maritimus, increased two- to threefold from high to low flow current sites, with no differences between habitats. These estimates include the sandy layers related to the artificial opening of the Faro-Olhão inlet that, albeit being characteristic of this system, do not represent the storage of car- bon by vegetated habitats. If the sand layers are excluded from OC and TN estimates of stocks, the negative trend of $\mathrm{OC}$ and $\mathrm{TN}$ stocks from low to high current flow sites is still apparent (Figure 6), albeit less pronounced, and the stock of SM2 stands out as an outlier. Before the artificial opening of the nearby inlet, this was probably a more privileged site of OC and TN sequestration where hydrodynamics was certainly much lower and where the sudden accumulation of sand may have lowered organic matter decomposition. In fact, this is very evident at station SM2, where the OC and TN contents are similar above and below the sand intrusion (Figure 2).

Similarly, the OC and TN burial rates increased from sheltered to exposed sites by twofold in $S$. maritimus and by almost an order of magnitude in $Z$. noltei. A similar variation pattern along the same stations was observed for the upper $5 \mathrm{~cm}$ OC and TN sedimentary stocks of $Z$. noltei, which increased 3- and 2.4-fold, respectively, but not for S. maritimus (Santos and others 2019). The negative relationship of flow current with stocks was not as pronounced in superficial layers, were disturbances such as bioturbation and clam harvesting enhance the oxidation of organic matter. The use of the system by clam and bait harvesters has increased during the last decades following the general population and touristic demand growth, increasing the disturbance of surface sediments and probably decreasing their carbon storage. This highlights the disadvantages of using short sediment cores (for example, $25 \mathrm{~cm}$ ) to estimate sedimentary OC and TN stocks for the upper $1 \mathrm{~m}$ of sediment (for example, as in Fourqurean and others 2012; Lavery and others 2013; Röhr and others 2018). 

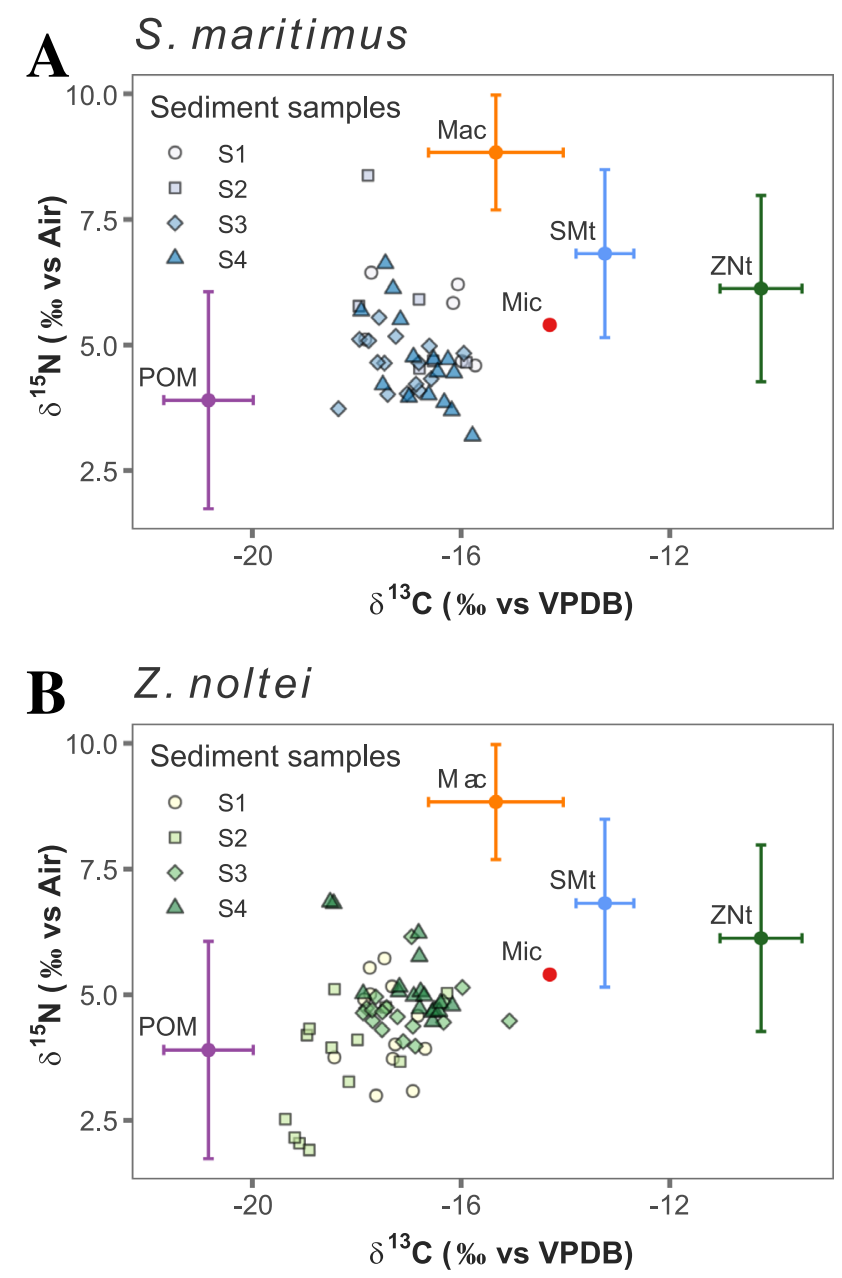

Figure 4. Bi-plot of isotopic signatures $\left(\delta^{13} \mathrm{C}\right.$ and $\left.\delta^{15} \mathrm{~N}\right)$ of the sediment samples across stations (from the most exposed station, S1, to most sheltered one, S4) and organic matter sources (mean $\pm \mathrm{SD}$ ) at the Sporobolus maritimus (A) and Zostera noltei (B) habitats. Sources are: particulate organic matter (POM, $n=19$ ), macroalgae (Mac, $n=12$ ), microphytobenthos (Mic, $n=1$ ), tissues of S. maritimus (SMt, $n=18$ ), tissues of Z. noltei (ZNt, $n=18$ ).

The negative relationship between high flow velocities and carbon storage and sequestration in seagrass meadows is supported by previous reports of such a relationship with hydrodynamic energy, assessed in different ways, including wave height and coastal exposure (Hasegawa and others 2008; Kindeberg and others 2018; Jankowska and others 2016; Samper-Villarreal and others 2016; Serrano and others 2016a, b; Mazarrasa and others 2017; Dahl and others 2018). Spatial gradients of OC and TN stocks in seagrass sediments within coastal systems such as tidal lagoons and estuaries where current flow is highly variable must then be considered in blue carbon estimates (Ricart and others 2020). Similar patterns were described for saltmarsh sediments, which contain more fine particles and higher organic matter contents in more sheltered areas (Kelleway and others 2016; Macreadie and others 2017). The differences in mud contents along hydrodynamic gradients, which are resuspended above specific thresholds of flow (Friend and others 2003), can also influence the potential for carbon sequestration within the sediments of vegetated habitats, as small particles compact more, decreasing oxygenation and thus the mineralization rates of organic matter (Ricart and others 2015; Serrano and others 2016a, b).

In spite of the vast literature highlighting the negative relationship between hydrodynamic regime and storage of organic carbon within seagrasses and saltmarshes, the mechanistic understanding of the interactions among the system components that explain the observations is less well known. In shallow coastal ecosystems, plant canopies create a strong drag, attenuating waves and reducing the water flow current (Moki 


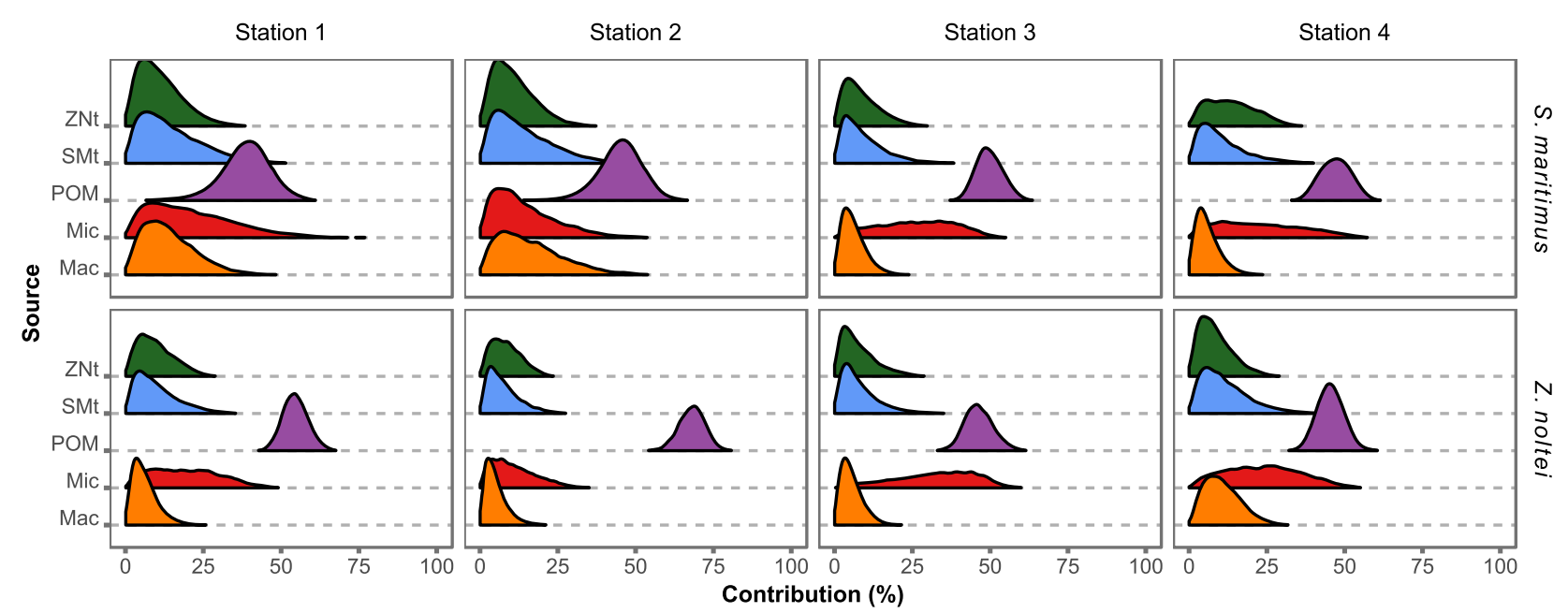

Figure 5. Kernel density plots of the contributions (\%) of the organic matter sources to Sporobolus maritimus (A) and Zostera noltei (B) habitats, derived by the stable isotope mixing models, at the four sampling stations (from the most exposed station, S1, to most sheltered one, S4). Sources are: particulate organic matter (POM), macroalgae (Mac), microphytobenthos (Mic), tissues of S. maritimus (SMt) and tissues of Z. noltei (ZNt).
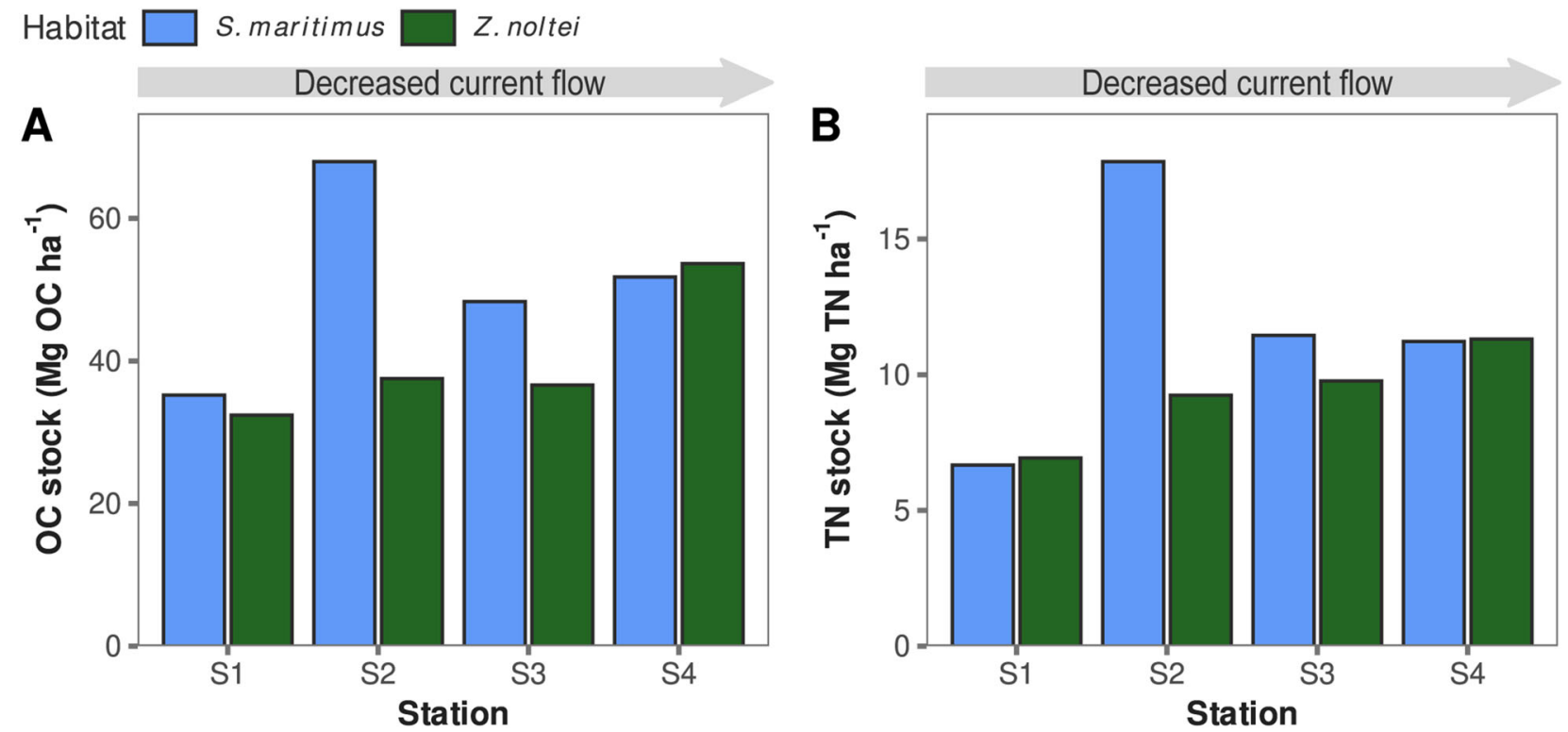

Figure 6. Stocks of (A) organic carbon (OC) and (B) total nitrogen (TN) (Mg ha-1), in the sediment of Sporobolus maritimus and Zostera noltei along the current flow gradient, from sampling stations S1 to S4, when excluding the sandy layers that resulted from the Faro-Olhão inlet opening.

and others 2020), thus enhancing fine sediment deposition including organic matter (Gacia and others 1999; Bouma and others 2005). This process can lead to reduced particle suspension and increased sediment bed stability (Terrados and Duarte 2000), but there are also reports of enhanced turbulence (Shan and others 2020; Yager and Schmeeckle 2013; Yang and Nepf 2018), increasing fine sediment resuspension and transport (Cheng and Emadzadeh 2017). The understanding of these opposing processes is critical for understanding the carbon deposition in seagrasses and saltmarshes. As well, the prediction of the hydrodynamic drag experienced by seagrass and saltmarsh plants, which can present a wide range of morphologies and structural and mechanical traits (Tempest and others 2015; de los Santos and others 2016), has hindered the development of models of wave and flow attenuation (Zhang and Nepf 2021), and thus 
the modelling of carbon sequestration by coastal ecosystems.

\section{Contributions to Sedimentary Organic Matter}

Autochthonous organic matter, which includes the main macrophytes and microphytobenthos, contributes with $20-40 \%$ of the sedimentary OC and TN stocks of both vegetated habitats in Ria Formosa lagoon, supporting the results previously obtained for superficial sediments (Santos and others 2019). The autochthonous contribution within $Z$. noltei of Ria Formosa is similar to the most common values reported for other seagrasses (for example, Kennedy and others 2010; Miyajima and others 2015; Röhr and others 2018). Data on saltmarshes are scarcer than on seagrasses, suggesting that autochthonous contributions increase with elevation and range from 30 to $60 \%$ (Zhou and others 2006; Gebrehiwet and others 2008; Craven and others 2017).

The specific contribution of Z. noltei to their own sedimentary OC stock, from 8 to $10 \%$, is lower than what has been reported for other species, from 20 to $80 \%$ (Kennedy and others 2010; Jankowska and others 2016; Serrano and others 2016a, b). The low contribution observed in Ria Formosa probably results from the leaf traits of $Z$. noltei, as other small seagrasses, with low biomass density and up to $60 \%$ of aerenchyma tissue (Silva and Santos 2004), which results in high buoyancy and facilitated tidal transport to adjacent habitats. Sporobolus maritimus tissues contributed slightly more to their own sediment, between 9 and $14 \%$. The high allochthonous contribution in seagrasses, mostly from POM, reinforces the importance of submerged vegetation at decreasing the water turbidity by trapping suspended particles, an ecological process that underlines one of their main ecosystem services, water filtration (Bouma and others 2005; Hendriks and others 2008).

\section{OC and TN Stocks and Burial Rates in a Global Context}

The sedimentary OC stocks in the upper meter of $Z$. noltei in Ria Formosa lagoon ranged from 29 to $99 \mathrm{Mg}$ OC $\mathrm{ha}^{-1}$, much lower than the global average of OC stocks in seagrasses $(140 \pm 370 \mathrm{Mg}$ OC ha $^{-1}$; Fourqurean and others 2012). However, the global estimate is highly skewed towards the large Mediterranean seagrass species, Posidonia oceanica (Lavery and others 2013), for which stocks may attain up to $740 \mathrm{Mg} \mathrm{OC} \mathrm{ha}^{-1}$ in the first meter of sediment (Serrano and others 2014). In a recent study in Australia, the mean stock of blue carbon in seagrass sediments was estimated as $112 \pm 88 \mathrm{Mg}$ OC ha-1 (Serrano and others 2019). The values we obtained for Ria Formosa are lower than those of the congeneric species, Z. marina, that range from 72 to $140 \mathrm{Mg} \mathrm{OC} \mathrm{ha}^{-1}$ (Miyajima and others 2015; Röhr and others 2018; Green and others 2018).

As for the OC burial rates within $Z$. noltei sediments, they ranged from $15 \mathrm{~g} \mathrm{OC} \mathrm{m}^{2} \mathrm{y}^{-1}$ at the high flow current site to $122 \mathrm{~g} \mathrm{OC}^{2} \mathrm{y}^{-1}$ at the low flow current site. This is a wide range of values, in the same order of the range reported for Posidonia spp. (2-140 g OC $\mathrm{m}^{2} \mathrm{y}^{-1}$; Serrano and others 2014) and of the average sequestration rates in seagrasses in Australia $\left(36 \pm 30 \mathrm{~g} \mathrm{OC}^{2} \mathrm{y}^{-1}\right.$; Serrano and others 2019). There are no other available estimates for $Z$. noltei, but burial rates in $Z$. marina are similar, ranging from $3 \mathrm{~g} \mathrm{OC} \mathrm{m}^{2} \mathrm{y}^{-1}$ (Miyajima and others 2015) to $93 \mathrm{~g} \mathrm{OC}^{2} \mathrm{y}^{-1}$ (Prentice and others 2020). A global estimate for seagrass burial rates of $138 \pm 38 \mathrm{~g} \mathrm{OC} \mathrm{m}^{2} \mathrm{y}^{-1}$ was published by Mcleod and others (2011), a value that is certainly overestimated (Lavery and others 2013) and that has been recently revised to be between 20 and $30 \mathrm{~g} \mathrm{OC} \mathrm{m}^{2} \mathrm{y}^{-1}$ (Arias-Ortiz 2019).

The OC stocks estimated in S. maritimus at Ria Formosa lagoon were similar to $Z$. noltei, ranging from 29 to $101 \mathrm{Mg} \mathrm{OC} \mathrm{ha}^{-1}$, lower than the stock range reported in the literature, 237-949 Mg OC $\mathrm{ha}^{-1}$ (Pendleton and others 2012). The burial rates estimated in the lagoon, from 19 to $39 \mathrm{~g} \mathrm{OC} \mathrm{m}^{-2} \mathrm{y}^{-1}$, indicate limited OC sequestration by saltmarshes, as they are lower than the values reported in a recent, thorough review (Ouyang and Lee 2014). The global geographic estimates range from an average of $172 \pm 18 \mathrm{~g} \mathrm{OC} \mathrm{m}^{-2} \mathrm{y}^{-1}$ in NW Atlantic to $315 \pm 63 \mathrm{~g} \mathrm{OC} \mathrm{m}^{-2} \mathrm{y}^{-1}$ in $\mathrm{N}$ Europe. Average values for Southern Europe of $306 \pm 86 \mathrm{~g} \mathrm{OC} \mathrm{m}^{-2}$ $\mathrm{y}^{-1}$ are also much higher than those found at Ria Formosa lagoon. One explanation for this is that most of the studied saltmarshes are in estuaries, where terrestrial inputs of organic matter are important, as opposed to those in Ria Formosa where there are no major rivers and the $\mathrm{C}$ discharges from streams are negligible (Malta and others 2017). In fact, while the $\delta^{13} \mathrm{C}$ of sedimentary organic matter in the vegetated habitats of Ria Formosa ranges from - 19.4 to - 15.1\% (mean $-17.2 \%$ ), in estuarine saltmarshes, it ranges from -24.5 to $-14 \%$ (mean $-19.9 \%$ ). The most depleted ${ }^{13} \mathrm{C}$ values in estuarine saltmarshes are indicative of terrestrial carbon inputs. 
As opposed to OC stocks, estimates of TN stocks and burial rates in vegetated coastal habitats are very scarce. To the best of our knowledge, this is the first assessment of TN stocks and burial rates for the seagrass species $Z$. noltei, which ranged from 7 to $11 \mathrm{Mg} \mathrm{ha}^{-1}$ and from 2 to $14 \mathrm{~g} \mathrm{~m}^{-2} \mathrm{y}^{-1}$, respectively. These TN stocks are higher than those reported elsewhere, as those of Z. marina along the Danish coast (Kindeberg and others 2018), from 0.2 to $4 \mathrm{Mg} \mathrm{ha}^{-1}$, and those of the Red Sea and the Arabian Gulf seagrasses, 0.6 and $3 \mathrm{Mg} \mathrm{ha}^{-1}$, respectively (Saderne and others 2020). Similarly, burial rates of TN in Z. noltei meadows in Ria Formosa are also higher than elsewhere, for example, for seagrasses of the Red Sea and the Arabian Gulf, 0.5 and $2.2 \mathrm{~g} \mathrm{TN} \mathrm{m}^{-2} \mathrm{y}^{-1}$, respectively (Saderne and others 2020), of Shark Bay, Australia, $2.9 \mathrm{~g} \mathrm{TN}$ $\mathrm{m}^{-2} \mathrm{y}^{-1}$ (Saderne and others 2020), of estuarine systems of New South Wales, Australia, 1.3 to $8.2 \mathrm{~g}$ $\mathrm{TN} \mathrm{m}{ }^{-2} \mathrm{y}^{-1}$ (Eyre and others 2016), and of Virginia, USA, $3.5 \mathrm{~g} \mathrm{TN} \mathrm{m}^{-2} \mathrm{y}^{-1}$ (Aoki and others 2019).

The TN stocks of $S$. maritimus in the Ria Formosa ranged from 3 to $11 \mathrm{Mg} \mathrm{TN} \mathrm{ha}{ }^{-1}$. These stocks are similar to those reported in a restored $S$. maritimus marsh in Huelva estuary (Spain), $4.2 \mathrm{Mg} \mathrm{ha}^{-1}$ (Curado and others 2013). The TN burial rates of S. maritimus in the Ria Formosa, from 3 to $5 \mathrm{~g} \mathrm{TN} \mathrm{m}^{-2}$ $\mathrm{y}^{-1}$, are higher than the saltmarshes of Saudi Arabia, $0.7-0.18 \mathrm{~g} \mathrm{TN} \mathrm{m} \mathrm{gr}^{-2} \mathrm{yr}^{-1}$ (Saderne and others 2020) and similar to those of the Bay of Cadiz, Spain, 3-4.4 g TN m ${ }^{-2} \mathrm{y}^{-1}$ (Jiménez-Arias and others 2020), and of Cape Fear River in North Carolina (USA), $5 \mathrm{~g} \mathrm{TN} \mathrm{m}^{-2} \mathrm{y}^{-1}$ (Noll and others 2019). On the other hand, TN burial rates in Ria Formosa are much lower that the rates reported in the Ria de Aveiro, Mondego and Tagus estuaries, Portugal, ranging from 23.3 to $61.3 \mathrm{~g} \mathrm{TN} \mathrm{m}^{-2} \mathrm{y}^{-1}$ (Sousa and others 2008, 2017). As previously noted for OC burial, these systems show very high TN burial rates because they are located in estuaries of large rivers, where there are large inputs and accumulation of terrestrial organic matter and nutrients.

In conclusion, the variability of OC and TN stocks and burial rates within vegetated habitats of Ria Formosa lagoon is large, mainly due to important gradients in the flow current velocities from main inlets and main navigation channels, with high current flow velocities, to secondary and tertiary channels, with low current flow velocities (Santos and others 2019). High variability of stocks and burial rates has also been reported at a global scale, for example, OC stocks in seagrasses may vary up to 46 -fold, much more than the previous 18 -fold re- ported in Lavery and others (2013). This highlights the importance of both investigating the drivers of that spatial variability and developing spatially explicit models to estimate global patterns in blue carbon and nitrogen sequestration and storage. Our long-term approach study, as in the previous shortterm approach (Santos and others 2019), shows that current flow velocity is a major driver. Yet, the influence of other factors, such as the inputs of organic matter loads that may vary with the type of systems, for example, open coast, coastal lagoons or estuaries, or the sediment conditions for organic matter mineralization, needs to be investigated.

The data reported here add to the growing number of estimates of organic carbon stocks of blue carbon ecosystems, particularly of underrepresented species such as the seagrass $Z$. noltei and the saltmarsh $S$. maritimus, to reduce current uncertainties of the global quantification of blue carbon. We provided here the second estimate of OC carbon stocks and the first estimate of OC burial rates of $Z$. noltei, a small, fast growing species, that is widely distributed in Europe and which area is presently recovering in many locations (de los Santos and others 2019). Z. noltei TN stocks and burial rates in Ria Formosa were generally higher than those reported in other seagrass habitats. Uncertainties also hinder saltmarsh global estimates of carbon stocks and burials owing to limited data availability (Ouyang and Lee 2014; Arias-Ortiz and others 2018). We showed here that the OC and TN stocks and burial rates of $S$. maritimus in Ria Formosa were much lower than those reported elsewhere in estuaries, as there are no significant river flows into the lagoon, which deliver high loads of sediments and organic matter to estuaries.

It is highly relevant to narrow current uncertainties in the estimates of blue carbon contributions by seagrasses and saltmarshes to the ocean carbon budget so that these can be incorporated into future representations of the global carbon budgets by the IPCC (Duarte 2017). In particular for seagrasses, global estimates are skewed for larger species (Lavery and others 2013) and data on small, fast-growing species with wide geographical distributions, such as those presented here for $Z$. noltei, are needed.

\section{ACKNOWLEDGEMENTS}

Foundation of Science and Technology of Portugal (FCT) funded this work through projects PTDC/ MAR-EST/3223/2014, PTDC/MAR-EST/1031/ 2014, UIDP/00350/2020 and UIDB/04326/2020. C.B.d.l.S. was supported by FCT fellowship SFRH/ 
BPD/1 19344/2016 and A.R.C. by FCT under the DL 57/2016/CP1361/CT0002. Funding was provided to P.M. by the Generalitat de Catalunya (Grant 2017 SGR-1588) and through an Australian Research Council LIEF Project (LE170100219). This work is contributing to the Institut de Ciència i Tecnologia Ambientals (ICTA) "Unit of Excellence" (MinECo, MDM2015-0552). The International Atomic Energy Agency (IAEA) is grateful for the support provided to its Environment Laboratories by the Government of the Principality of Monaco. We thank A. Silva, J. Dupont and C. Freitas for the assistance in the field and laboratory work and the Olhão Marina/Verbos do Cais, S.A. for their support in the use of the marina.

\section{Declarations}

Conflict of interest The authors declare that they have no conflict of interest.

\section{REFERENCES}

Aoki LR, McGlathery KJ, Oreska MPJ. 2019. Seagrass restoration reestablishes the coastal nitrogen filter through enhanced burial. Limnol Oceanogr 65:1-12.

Appleby PG, Oldfield F. 1978. The calculation of lead-210 dates assuming a constant rate of supply of unsupported ${ }^{210} \mathrm{~Pb}$ to the sediment. Catena 5:1-8.

Arias-Ortiz A. 2019. Carbon sequestration rates in coastal blue carbon ecosystems: a perspective on climate change mitigation. Ph.D. Thesis, Universitat Autonoma de Barcelona, 227 p.

Arias-Ortiz A, Masqué P, Garcia-Orellana J, Serrano O, Mazarrasa I, Marbà N, Lovelock CE, Lavery PS, Duarte CM. 2018. Reviews and syntheses: ${ }^{210} \mathrm{~Pb}$-derived sediment and carbon accumulation rates in vegetated coastal ecosystems-setting the record straight. Biogeosciences 15:6791-6818.

Bergamaschi BA, Tsamakis E, Keil RG, Eglinton TI, Montluçon DB, Hedges JI. 1997. The effect of grain size and surface area on organic matter, lignin and carbohydrate concentration, and molecular compositions in Peru Margin sediments. Geochem Cosmochim Acta 61:1247-1260.

Bouma TJ, Vries MD, Low E, Kusters L, Herman PMJ, Tanczos IC, Temmerman S, Hesselink A, Meire P, Van Regenmortel S. 2005. Flow hydrodynamics on a mudflat and in salt marsh vegetation: identifying general relationships for habitat characterisations. Hydrobiologia 540(1-3):259-274.

Bulmer RH, Schwendenmann L, Lundquist CJ. 2016. Carbon and nitrogen stocks and below-ground allometry in temperate mangroves. Front Mar Sci 3:150.

Burdige DJ. 2007. Preservation of organic matter in marine sediments: controls, mechanisms, and an imbalance in sediment organic carbon budgets? Chem Rev 107:467-485.

Cabaço S, Alexandre A, Santos R. 2005. Population-level effects of clam harvesting on the seagrass Zostera noltii. Mar Ecol Progr Ser 298:123-129.

Carrasco AR, Plomaritis T, Reyns J, Ferreira O, Roelvink D. 2018. Tide circulation patterns in a coastal lagoon under sea-level rise. Ocean Dyn 68:1121-1139.
Cheng N, Emadzadeh A. 2017. Laboratory measurements of vortex-induced sediment pickup rates. Int J Sedim Res 32:98104.

Christiansen T, Wiberg PL, Milligan TG. 2000. Flow and sediment transport on a tidal salt marsh surface. Estuar Coast Shelf Sci 50:315-331.

Craven KF, Edwards RJ, Flood RP. 2017. Source organic matter analysis of saltmarsh sediments using SIAR and its application in relative sea-level studies in regions of $\mathrm{C} 4$ plant invasion. Boreas 46:642-654.

Cunha AH, Assis JF, Serrão E. 2013. Seagrasses in Portugal: a most endangered marine habitat. Aquat Bot 104:193-203.

Curado G, Rubio-Casal AE, Figueroa E, Grewell BJ, Castillo JM. 2013. Native plant restoration combats environmental change: development of carbon and nitrogen sequestration capacity using small cordgrass in European salt marshes. Environ Monit Assess 185:8439-8449.

Dahl M, Deyanova D, Gütschow S, Asplund ME, Lyimo LD, Karamfilov V, Santos R, Björk M, Gullström M. 2016. Sediment properties as important predictors of carbon storage in Zostera marina meadows: a comparison of four European areas. PLoS ONE 11(12):e0167493.

Dahl M, Infantes E, Clevesjö R, Linderholm HW, Björk M, Gullström M. 2018. Increased current flow enhances the risk of organic carbon loss from Zostera marina sediments: insights from a flume experiment. Limnol Oceanogr 63(6):2793-2805.

Deegan LA, Johnson DS, Warren RS, Peterson BJ, Fleeger JW, Fagherazzi S, Wollheim WM. 2012. Coastal eutrophication as a driver of salt marsh loss. Nature 490(7420):388-392.

de los Santos C, Onoda Y, Vergara J, Pérez-Lloréns J, Bouma T, La Nafie Y, Cambridge M, Brun F. 2016. A comprehensive analysis of mechanical and morphological traits in temperate and tropical seagrass species. Mar Ecol Prog Ser 551:81-94.

de los Santos CB, Krause-Jensen D, Alcoverro T, Marbà N, Duarte CM, van Katwijt MM, et al. 2019. Recent trend reversal for declining European seagrass meadows. Nat Commun 10:3356.

Duarte CM. 2017. Reviews and syntheses: Hidden forests, the role of vegetated coastal habitats in the ocean carbon budget. Biogeosciences 14:301-310.

Duarte CM, Kennedy H, Marbà N, Hendriks I. 2013. Assessing the capacity of seagrass meadows for carbon burial: Current limitations and future strategies. Ocean Coast Manag 83:3238.

Duarte CM, Middelburg JJ, Caraco N. 2005. Major role of marine vegetation on the oceanic carbon cycle. Biogeosciences 2:1-8.

Erisman JW, Galloway JN, Seitzinger S, Bleeker A, Dise NB, Petrescu AR, Leach AM, de Vries W. 2013. Consequences of human modification of the global nitrogen cycle. Philos Trans R Soc B Biol Sci 368(1621):20130116.

Eyre BD, Maher DT, Sanders C. 2016. The contribution of denitrification and burial to the nitrogen budgets of three geomorphically distinct Australian estuaries: importance of seagrass habitats. Limnol Oceanogr 61:1144-1156.

Ferreira Ó, Matias A, Pacheco A. 2016. The East coast of Algarve: a barrier island dominated coast. Thalass Int J Mar Sci 32:7585.

Fourqurean JW, Duarte CM, Kennedy H, Marbà N, Holmer M, Mateo MA, Apostolaki ET, Kendrick G, Krause-Jensen D, McGlathery KJ, Serrano O. 2012. Seagrass ecosystems as a globally significant carbon stock. Nat Geosci 5(7):505-509. 
Friend PL, Ciavola P, Cappucci S, Santos R. 2003. Bio-dependent bed parameters as a proxy tool for sediment stability in mixed habitat intertidal areas. Contin Shelf Res 23(17-19):18991917.

Gacia E, Granata TC, Duarte CM. 1999. An approach to measurement of particle flux and sediment retention within seagrass (Posidonia oceanica) meadows. Aquat Bot 65:255-268.

Gebrehiwet T, Koretsky CM, Krishnamurthy RV. 2008. Influence of Spartina and Juncus on saltmarsh sediments. III. Organic geochemistry. Chem Geol 255:114-119.

Glew JR, Smol JP, Last WM. 2001. Sediment core collection and extrusion. In: Last WM, Smol JP, Eds. Tracking environmental change using lake sediments. Vol. 1. New York: Springer. pp 73-105.

Green A, Chadwick MA, Jones PJS. 2018. Variability of UK seagrass sediment carbon: implications for blue carbon estimates and marine conservation management. PLOS ONE 13:e0204431.

Hasegawa N, Hori M, Mukai H. 2008. Seasonal changes in eelgrass functions: current velocity reduction, prevention of sediment resuspension, and control of sediment-water column nutrient flux in relation to eelgrass dynamics. Hydrobiologia 596:387-399.

Hendriks IE, Sintes T, Bouma TJ, Duarte CM. 2008. Experimental assessment and modeling evaluation of the effects of the seagrass Posidonia oceanica on flow and particle trapping. Mar Ecol Progr Ser 356:163-173.

Hyndes GA, Nagelkerken I, Mcleod RJ, Connolly RM, Lavery PS, Vanderklift MA. 2014. Mechanisms and ecological role of carbon transfer within coastal seascapes. Biol Rev 89

IPCC. 2019. Climate Change and Land: an IPCC special report on climate change, desertification, land degradation, sustainable land management, food security, and greenhouse gas fluxes in terrestrial ecosystems.

Jacob J, Cardeira S, Rodrigues M, Bruneau N, Azevedo A, Fortunato AB, Rosa M, Cravo A. 2013. Experimental and numerical study of the hydrodynamics of the western sector of Ria Formosa. J Coast Res 65:2011-2016.

Jankowska E, Michel LN, Zaborska A, Włodarska-Kowalczuk M. 2016. Sediment carbon sink in low-density temperate eelgrass meadows (Baltic Sea). J Geophys Res Biogeosci 121:29182934.

Jiménez-Arias JL, Morris EP, Rubio-de-Inglés MJ, Peralta G, García-Robledo E, Corzo A, Papaspyrou S. 2020. Tidal elevation is the key factor modulating burial rates and composition of organic matter in a coastal wetland with multiple habitats. Sci Total Environ 724:138205.

Jordan SJ, Stoffer J, Nestlerode JA. 2011 . Wetlands as sinks for reactive nitrogen at continental and global scales: a metaanalysis. Ecosystems 14(1):144-155.

Kelleway JJ, Saintilan N, Macreadie PI, Ralph PJ. 2016. Sedimentary factors are key predictors of carbon storage in SE Australian saltmarshes. Ecosystems 19:865-880.

Kennedy H, Beggins J, Duarte CM, Fourqurean JW, Holmer M, Marbà N, Middelburg JJ. 2010. Seagrass sediments as a global carbon sink: isotopic constraints. Glob Biogeochem Cycles 24(4):GB4026.

Kindeberg T, Ørberg SB, Röhr ME, Holmer M, Krause-Jensen D. 2018. Sediment stocks of carbon, nitrogen, and phosphorus in Danish eelgrass meadows. Front Mar Sci 5:474.

Koho KA, Nierop KGJ, Moodley L, Middelburg JJ, Pozzato L, Soetaert K, van der Plicht J, Reichart GJ. 2013. Microbial bioavailability regulates organic matter preservation in marine sediments. Biogeosciences 10:1131-1141.

Krishnaswamy S, Lal D, Martin JM, Meybeck M. 1971. Geochronology of lake sediments. Earth Planet Sci Lett 11:407-414.

Lavery PS, Mateo M-Á, Serrano O, Rozaimi M. 2013. Variability in the carbon storage of seagrass habitats and its implications for global estimates of blue carbon ecosystem service. PLoS ONE 8:e73748.

Machás R, Santos R, Peterson B. 2003. Tracing the flow of organic matter from primary producers to filter feeders in Ria Formosa lagoon, Southern Portugal. Estuaries 26(4):846-856.

Macreadie PI, Anton A, Raven JA, Beaumont N, Connolly RM, Friess DA, Kelleway JJ, Kennedy H, Kuwae T, Lavery PS, et al. 2019. The future of blue carbon science. Nat Commun 10:113.

Macreadie PI, Baird ME, Trevathan-Tackett SM, Larkum AWD, Ralph PJ. 2014. Quantifying and modelling the carbon sequestration capacity of seagrass meadows-a critical assessment. Mar Pollut Bull 83(2):430-439.

Macreadie PI, Ollivier QR, Kelleway JJ, Serrano O, Carnell PE, Ewers Lewis C, Atwood TB, Sanderman J, Baldock J, Connolly RM, Duarte CM, Lavery PS, Lovelock CE. 2017. Carbon sequestration by Australian tidal marshes. Sci Rep 7:44071.

Malta EJ, Stigter TY, Pacheco A, Dill AC, Tavares D, Santos R. 2017. Effects of external nutrient sources and extreme weather events on the nutrient budget of a southern European coastal lagoon. Estuaries Coasts 40(2):419-436.

Mateo MA, Romero J, Pérez M, Littler MM, Littler DS. 1997. Dynamics of millenary organic deposits resulting from the growth of the Mediterranean SeagrassPosidonia oceanica. Estuar Coast Shelf Sci 44:103-110.

Mazarrasa I, Marbà N, Garcia-Orellana J, Masqué P, Arias-Ortiz A, Duarte CM. 2017. Effect of environmental factors (wave exposure and depth) and anthropogenic pressure in the $\mathrm{C}$ sink capacity of Posidonia oceanica meadows. Limnol Oceanogr 62(4):1436-1450.

Mazarrasa I, Samper-Villarreal J, Serrano O, Lavery PS, Lovelock CE, Marbà N, Duarte CM, Cortés J. 2018. Habitat characteristics provide insights of carbon storage in seagrass meadows. Mar Pollut Bull 134:106-117.

Mcleod E, Chmura GL, Bouillon S, Salm R, Björk M, Duarte CM, Lovelock CE, Schlesinger WH, Silliman BR. 2011. A blueprint for blue carbon: toward an improved understanding of the role of vegetated coastal habitats in sequestering $\mathrm{CO}_{2}$. Front Ecol Environ 9(10):552-560.

Miyajima T, Hori M, Hamaguchi M, Shimabukuro H, Adachi $\mathrm{H}$, Yamano H, Nakaoka M. 2015. Geographic variability in organic carbon stock and accumulation rate in sediments of East and Southeast Asian seagrass meadows. Glob Biogeochem Cycles 29(4):397-415.

Moki H, Taguchi K, Nakagawa Y, Montani S, Kuwae T. 2020. Spatial and seasonal impacts of submerged aquatic vegetation (SAV) drag force on hydrodynamics in shallow waters. J Mar Syst 209:103373.

Murray NJ, Phinn SR, DeWitt M, Ferrari R, Johnston R, Lyons MB, Clinton N, Thau D, Fuller RA. 2019. The global distribution and trajectory of tidal flats. Nature 565(7738):222-225.

Nellemann C, Corcoran E, Duarte C, Valdes L, De Young C, Fonseca L, Grimsditch G. 2009. Blue Carbon. A Rapid Response Assessment. United Nations Environment Programme. 
Nellemann C, Corcoran E, Duarte C, Valdes L, De Young C, Fonseca L, Grimsditch G, editors. GRID-Arendal.

Noll A, Mobilian C, Craft C. 2019. Five decades of wetland soil development of a constructed tidal salt marsh, North Carolina, USA. Ecol Restor 37:163-170.

Ouyang X, Lee SY. 2014. Updated estimates of carbon accumulation rates in coastal marsh sediments. Biogeosciences 11:5057-5071.

Pacheco A, Ferreira Ó, Williams JJ. 2011. Long-term morphological impacts of the opening of a new inlet on a multiple inlet system. Earth Surf Process Landf 36:1726-1735.

Parnell AC, Inger R, Bearhop S, Jackson AL. 2010. Source partitioning using stable isotopes: coping with too much variation. PLoS ONE 5(3):e9672. https://doi.org/10.1371/journal. pone.0009672.

Parnell A. 2019. simmr: a stable isotope mixing model. https://c ran.r-project.org/web/packages/simmr/index.html.

Pendleton L, Donato DC, Murray BC, Crooks S, Jenkins WA, Sifleet S, Craft C, Fourqurean JW, Kauffman JB, Marbà N, et al. 2012. Estimating global "blue carbon" emissions from conversion and degradation of vegetated coastal ecosystems. PloS ONE 7(9):e43542.

Prentice C, Poppe KL, Lutz M, Murray E, Stephens TA, Spooner A, Hessing-Lewis M, Sanders-Smith R, Rybczyk JM, et al. 2020. A synthesis of blue carbon stocks, sources, and accumulation rates in eelgrass (Zostera marina) meadows in the Northeast Pacific. Glob Biogeochem Cycles 4(2):e2019GB006345.

R Core Team. 2018. R: A Language and Environment for Statistical Computing. R Foundation for Statistical Computing.

Ricart AM, York PH, Bryant CV, Rasheed MA, Ierodiaconou D, Macreadie PI. 2020. High variability of Blue Carbon storage in seagrass meadows at the estuary scale. Sci Rep 10(1):1-12.

Ricart AM, York PH, Rasheed MA, Pérez M, Romero J, Bryant CV, Macreadie PI. 2015. Variability of sedimentary organic carbon in patchy seagrass landscapes. Mar Pollut Bull 100:476-482.

Röhr ME, Boström C, Canal-Vergés P, Holmer M. 2016. Blue carbon stocks in Baltic Sea eelgrass (Zostera marina) meadows. Biogeosciences 13(22):6139-6153.

Röhr ME, Holmer M, Baum JK, Björk M, Boyer K, Chin D, Chalifour L, Cimon S, Cusson M, Dahl M, et al. 2018. Blue carbon storage capacity of temperate eelgrass (Zostera marina) meadows. Glob Biogeochem Cycles 32(10):1457-1475.

Saderne V, Cusack M, Serrano O, Almahasheer H, Krishnakumar PK, Rabaoui L, Qurban MA, Duarte CM. 2020. Role of vegetated coastal ecosystems as nitrogen and phosphorous filters and sinks in the coasts of Saudi Arabia. Environ Res Lett 15(3):034058.

Samper-Villarreal J, Lovelock CE, Saunders MI, Roelfsema C, Mumby PJ. 2016. Organic carbon in seagrass sediments is influenced by seagrass canopy complexity, turbidity, wave height, and water depth. Limnol Oceanogr 61:938-952.

Sánchez-Cabeza J, Masqué P, Ani-Ragolta I. 1998. ${ }^{210} \mathrm{~Pb}$ and ${ }^{210} \mathrm{Po}$ analysis in sediments and soils by microwave acid digestion. J Radioanal Nucl Chem 227(1-2):19-22.

Santos R, Duque-Núñez N, de los Santos CB, Martins M, Carrasco AR, Veiga-Pires C. . 2019. Superficial sedimentary stocks and sources of carbon and nitrogen in coastal vegetated assemblages along a flow gradient. Sci Rep 9(1):1-11.

Schmidt MWI, Torn MS, Abiven S, Dittmar T, Guggenberger G, Janssens IA, Kleber M, Kögel-Knabner I, Lehmann J, Manning DAC, et al. 2011. Persistence of soil organic matter as an ecosystem property. Nature 478:49-56.

Serrano O, Lavery PS, Duarte CM, Kendrick GA, Calfat A, York PH, Steven A, Macreadie PI. 2016a. Can mud (silt and clay) concentration be used to predict soil organic carbon content within seagrass ecosystems? Biogeosciences 13:4915-4926.

Serrano O, Almahasheer H, Duarte CM, Irigoien X. 2018. Carbon stocks and accumulation rates in Red Sea seagrass meadows. Sci Rep 8:15037.

Serrano O, Lavery PS, Rozaimi M, Mateo MÁ. 2014. Influence of water depth on the carbon sequestration capacity of seagrasses. Glob Biogeochem Cycles 28:950-961.

Serrano O, Lovelock CE, B. Atwood T, Macreadie PI, Canto R, Phinn S, Arias-Ortiz A, Bai L, Baldock J, Bedulli C, et al. 2019. Australian vegetated coastal ecosystems as global hotspots for climate change mitigation. Nat Commun 10:1-10.

Serrano O, Ricart AM, Lavery PS, Mateo MA, Arias-Ortiz A, Masque P, Rozaimi M, Steven A, Duarte CM. 2016b. Key biogeochemical factors affecting soil carbon storage in Posidonia meadows. Biogeosciences 13:4581-4594.

Shan Y, Zhao T, Liu C, Nepf H. 2020. Turbulence and bed load transport in channels with randomly distributed emergent patches of model vegetation. Geophys Res Lett 47:e2020GL087055.

Silva J, Santos R. 2004. Can chlorophyll fluorescence be used to estimate photosynthetic production in the seagrass Zostera noltii? J Exp Mar Biol Ecol 307:207-216.

Sousa AI, Lillebø AI, Caçador I, Pardal MA. 2008. Contribution of Spartina maritima to the reduction of eutrophication in estuarine systems. Environ Pollut 156:628-635.

Sousa AI, Santos DB, Da Silva EF, Sousa LP, Cleary DF, Soares AM, Lillebø AI. 2017. 'Blue carbon'and nutrient stocks of salt marshes at a temperate coastal lagoon (Ria de Aveiro, Portugal). Sci Rep 7(1):1-11.

Tempest JA, Möller I, Spencer T. 2015. A review of plant-flow interactions on salt marshes: the importance of vegetation structure and plant mechanical characteristics: salt marsh plant-flow interactions. Wires Water 2:669-681.

Terrados J, Duarte CM. 2000. Experimental evidence of reduced particle resuspension within a seagrass (Posidonia oceanica L.) meadow. J Exp Mar Biol Ecol 243:45-53. https://linkinghub.e lsevier.com/retrieve/pii/S0022098199001100

Yager EM, Schmeeckle MW. 2013. The influence of vegetation on turbulence and bed load transport: VEGETATION, TURBULENCE, BED LOAD FLUX. J Geophys Res Earth Surf 118:1585-1601.

Yang JQ, Nepf HM. 2018. A turbulence-based bed-load transport model for bare and vegetated channels. Geophys Res Lett 45:10,428-10,436. https://doi.org/10.1029/2018GL079319.

Zhang X, Nepf H. 2021. Wave-induced reconfiguration of and drag on marsh plants. J Fluids Struct 100:103192.

Zhou J, Wu Y, Zhang J, Kang Q, Liu Z. 2006. Carbon and nitrogen composition and stable isotope as potential indicators of source and fate of organic matter in the salt marsh of the Changjiang Estuary, China. Chemosphere 65:310-317. 